\title{
COMPARISON OF SEISMIC FRAGILITY CURVES FOR RC FRAMED BUILDINGS IN ZONE III AND V; FOR HARD, MEDIUM AND SOFT SOIL AS PER IS1893 PART-1: 2002 AND HAZUS MH 2.0
}

\author{
Dhara Shah ${ }^{1}$ \\ ${ }^{1}$ Assistant Professor, Faculty of Technology, CEPT University, Gujarat, India
}

\begin{abstract}
India, one of the most disastrous countries in the world has experienced several devastating earthquakes in the past resulting in casualties including property damage, deaths and injuries. The frequent occurrence of damaging earthquakes in India demands vulnerability assessment of structures especially residential buildings for disaster mitigation and emergency preparedness. In the present study seismic fragility curves are derived for low-rise, mid-rise and high-rise concrete buildings for seismic risk zone III and V considering hard, medium and soft soil as per IS1893 part-1(2002). Buildings are modeled using nonlinear platform. Pushover analysis is performed on the buildings to find their capacity curves. Damage states are established as per the hinge formation as well as HAZUS MH 2.0. Default spectra provided by IS1893 part-1 are used to select seismic events representing demand. Using Capacity Spectrum Method, displacements are obtained to create response matrix. Based on the damage states and the response matrix, fragility curves are constructed using Microsoft Excel. It is observed that buildings situated in soft soils are more vulnerable than those situated in medium and hard soil. Also, HAZUS underestimates the damage probability of the buildings and hence cannot be referred for Indian context. Site specific spectra are recommended for precision.
\end{abstract}

Keywords: - seismic fragility curves, RC framed building, IS1893 part-1:2002, HAZUS MH 2.0

\section{INTRODUCTION}

As per the current seismic zone map of India [1], 65\% of country's land is under moderate to very high seismic risk and the country has witnessed several major earthquakes in the past three decades. National Building Code of India [2] states that half of the total money spent on construction is consumed on buildings such as residential, commercial, industrial, medical, educational, etc. It is also estimated that about half of these total money spent on buildings is for housing. Seismic event in thickly populated urban zones with economic significance might call for numerous mortalities including extensive damage to building stocks. Hence it becomes vital to carry out vulnerability analysis of buildings to understand their damage probability for different intensity earthquake, which in turn will aid in preearthquake disaster planning as well as post-earthquake recovery programs. A fragility curve represents the probability that the structural damage of a structure, under various levels of seismic ground motions, exceed specified damage states. Fragility curves can be related to ground motion or permanent ground displacement. The damage state may be classified as Immediate Occupancy -IO, Life Safety-LS and Collapse Prevention - CP [3]. In accordance with the displacement bound limits, damage states are classified into four major categories: serviceable - I, repairable - II, near collapse - III and complete collapse - IV respectively. Many countries have developed earthquake loss analysis systems such as Hazards U.S. - HAZUS [4] and TELES [5]. These systems use fragility curves to estimate the damage probabilities of elements in a structure

\section{FRAGILITY FUNCTION TYPES}

Fragility curves can be classified as Empirical, Judgmental, Analytical and Hybrid. Empirical fragility curves use damage data from past earthquakes and are most realistic as all practical details of the site are taken care of. Its application is limited as empirical data are highly site specific [6]. Judgmental fragility curves are based on expert opinion as in ATC-13 [7] \& HAZUS. However, its reliability depends on the experience of the experts consulted and the nature of the subsequent relations [8]. Analytical fragility curves use numerical analysis, adopting damage distributions simulated from analyses of structural models under increasing earthquake intensity as their statistical basis. Generating artificial ground motions consistent with the site specification, and to relate numerical results of the simulation to predefined levels of damage are very challenging [8], [9]. Hybrid fragility curves are derived using the combination of all the above categories. In the present study, analytical fragility curves are derived.

A fragility curve is generally defined as a probabilistic relation between an Intensity measure (IM) and an engineering demand parameter (EDP), represented as a probability of exceeding an EDP given an IM or as probability of exceeding an IM given an EDP. Here intensity measure is in terms of seismic ground motion (PGA) and engineering demand parameter is in terms of displacement D [10]. 


\section{PROBLEM FORMULATION}

\subsection{Building Classification}

As per the literature reviewed, a residential building can be classified as low-rise, mid-rise, high-rise and skyscraper depending on the number of storey [11]. For the present study, hypothetical buildings taken into consideration are:

- Low-rise: Five storey tall building $(\mathrm{G}+4)$

- Mid-rise: Ten storey tall building $(\mathrm{G}+9)$

- High-rise: Fifteen storey tall building $(\mathrm{G}+14)$

\subsection{Building Geometry and Loading}

Typical plan and elevation for the hypothetical buildings under study is shown in figure 1, figure 2, figure 3 and figure 4 respectively. The buildings are designed for gravity loads as well as lateral loads as per Indian standards [12], [13],[14], [1], [15].

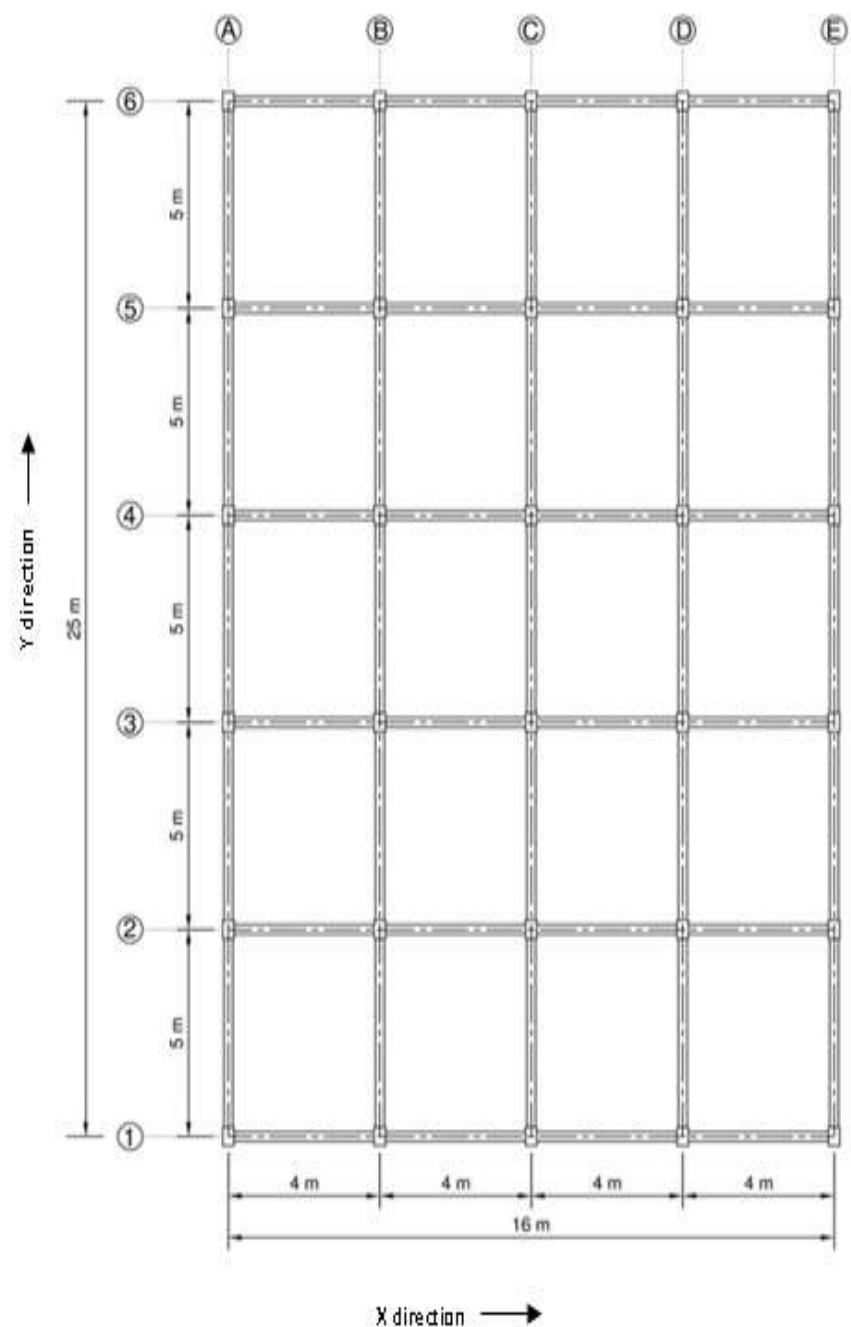

Fig - 1: Typical plan of building

The buildings are designed for seismic risk zone III and V, considering hard soil, medium soil and soft soil as per IS1893 part-1; in Gujarat. M25 grade of concrete and Fe415 steel reinforcement is used. Beam and column sizes have been designed as per hard soil in zone III and V such that the maximum percentage of steel reinforcement in beams and columns does not exceed $1.5 \%$ and $2.5 \%$ respectively.

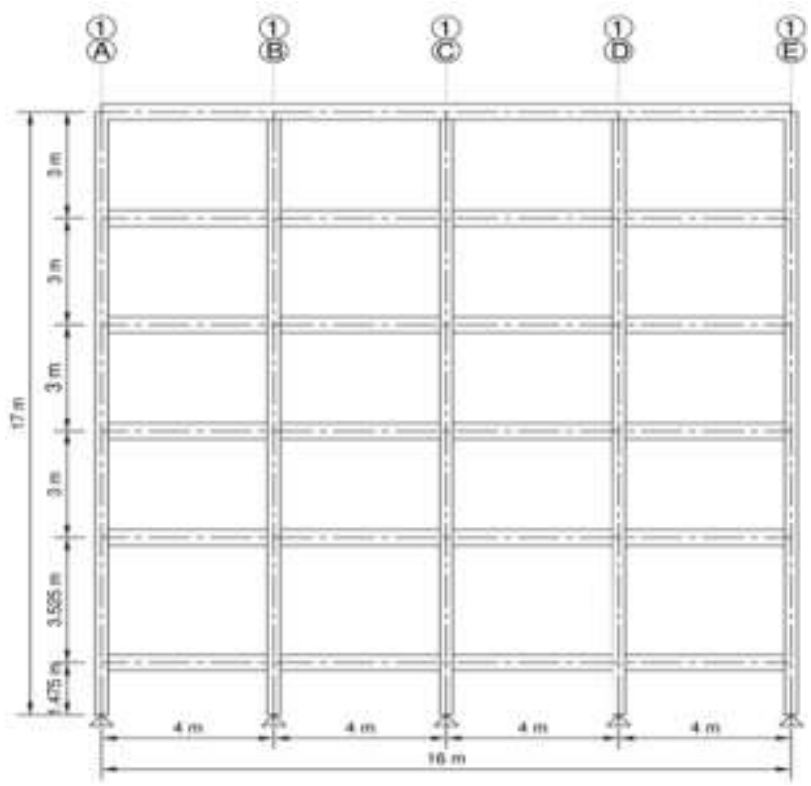

Fig - 2: Typical elevation of G+4 building

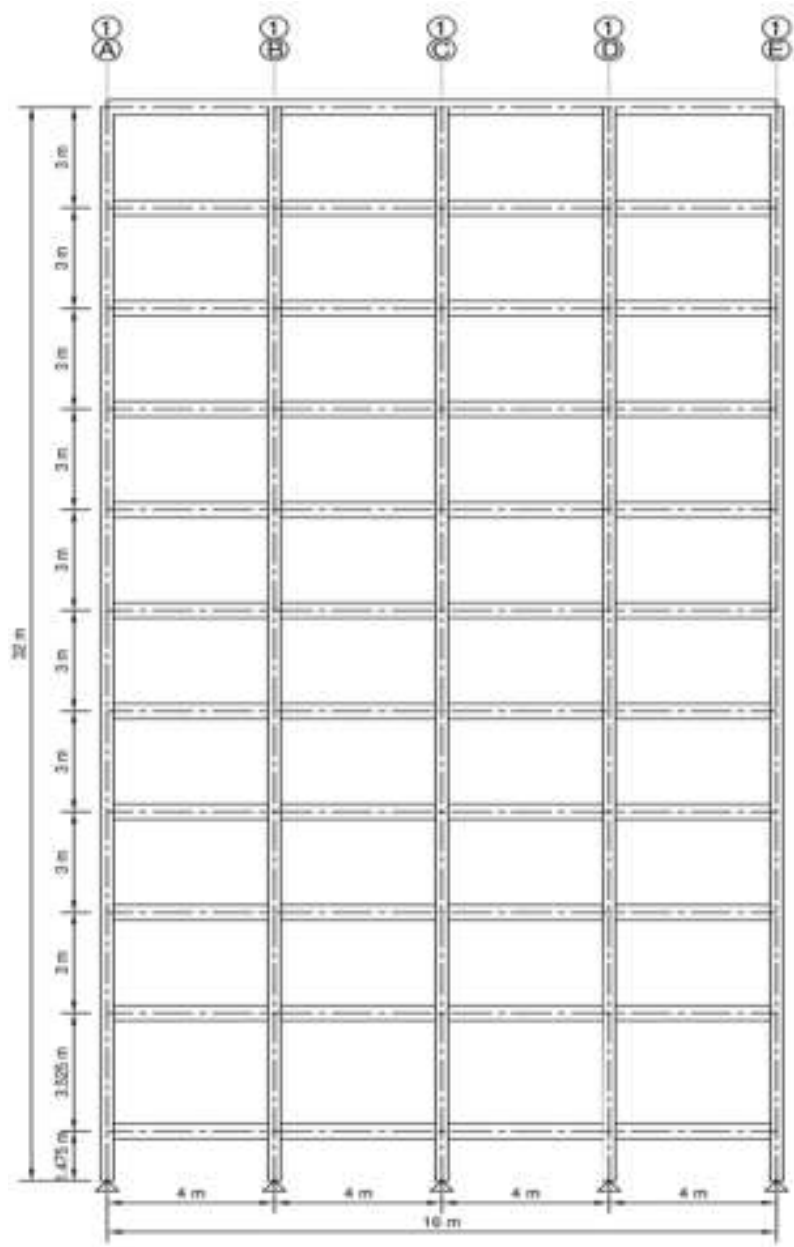

Fig - 3: Typical elevation of G+9 building 
The same sizes have been kept for medium and soft soil types. Table 1 and Table 2 shows the beam and column sizes used. Dead load and live load taken into consideration are given in Table 3. Peripheral brick walls are assumed 230 $\mathrm{mm}$ thick while interior walls and parapet walls are assumed $115 \mathrm{~mm}$ thick. Density of concrete, steel and brick assumed is $25 \mathrm{kN} / \mathrm{m}^{3}, \quad 78.5 \mathrm{kN} / \mathrm{m}^{3}$ and $20 \mathrm{kN} / \mathrm{m}^{3}$ respectively. Thickness of slab assumed is $125 \mathrm{~mm}$.

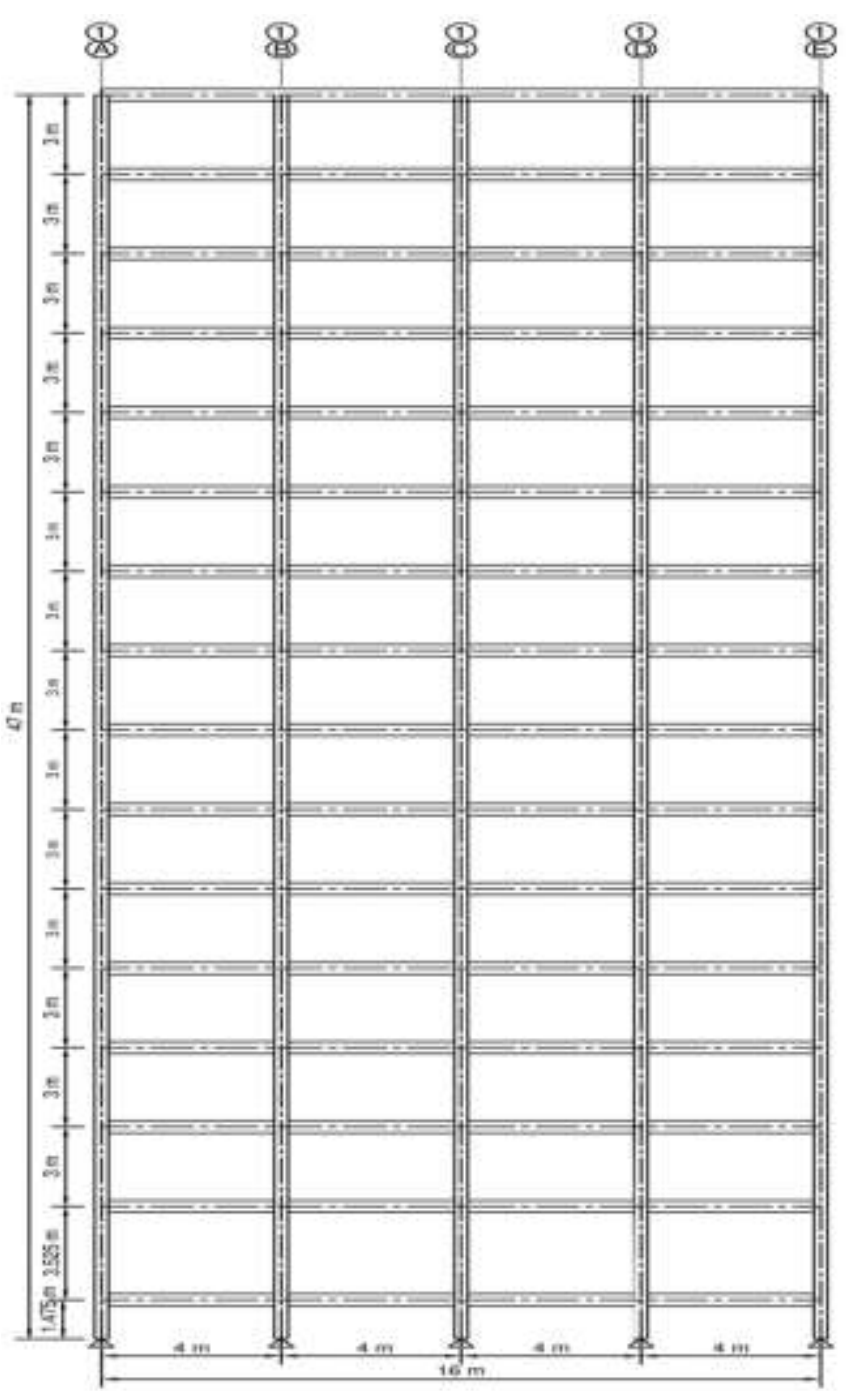

Fig - 4: Typical elevation of G+14 building

Table 1: Beam and column sizes for zone III buildings

\begin{tabular}{|c|c|c|c|c|c|c|c|}
\hline \multirow[b]{2}{*}{ Soil type } & \multirow[b]{2}{*}{$\begin{array}{l}\text { Ele } \\
\text { men } \\
\mathrm{t}\end{array}$} & \multicolumn{2}{|c|}{$\begin{array}{l}\text { Low rise } \\
\mathrm{G}+4\end{array}$} & \multicolumn{2}{|c|}{$\begin{array}{l}\text { Mid rise } \\
\mathrm{G}+9\end{array}$} & \multicolumn{2}{|c|}{$\begin{array}{l}\text { High rise } \\
G+14\end{array}$} \\
\hline & & $\begin{array}{l}\mathrm{B} \\
\mathrm{m} \\
\mathrm{m}\end{array}$ & $\begin{array}{l}\mathrm{D} \\
\mathrm{mm}\end{array}$ & $\begin{array}{l}\mathrm{B} \\
\mathrm{mm}\end{array}$ & $\begin{array}{l}\mathrm{D} \\
\mathrm{mm}\end{array}$ & $\begin{array}{l}\mathrm{B} \\
\mathrm{mm}\end{array}$ & $\begin{array}{l}\mathrm{D} \\
\mathrm{mm}\end{array}$ \\
\hline \multirow{2}{*}{$\begin{array}{l}\text { Hard, } \\
\text { Medium } \\
\text { soft }\end{array}$} & $\begin{array}{l}\text { Bea } \\
\mathrm{m}\end{array}$ & 230 & 450 & 230 & 450 & 230 & 450 \\
\hline & $\begin{array}{l}\text { Col } \\
\text { umn }\end{array}$ & 300 & 450 & 375 & 575 & 450 & 750 \\
\hline
\end{tabular}

*B $=$ Width, $\mathrm{D}=$ Depth
Table 2: Beam and column sizes for zone V buildings

\begin{tabular}{|l|l|l|l|l|l|l|l|}
\hline & & \multicolumn{2}{|l|}{$\begin{array}{l}\text { Low rise } \\
\text { G+4 }\end{array}$} & \multicolumn{2}{l|}{$\begin{array}{l}\text { Mid rise } \\
\text { G+9 }\end{array}$} & \multicolumn{2}{l|}{$\begin{array}{l}\text { High rise } \\
\text { G+14 }\end{array}$} \\
\hline $\begin{array}{l}\text { Soil } \\
\text { type }\end{array}$ & $\begin{array}{l}\text { Elem } \\
\text { ent }\end{array}$ & $\begin{array}{l}\text { B } \\
\mathrm{mm}\end{array}$ & $\begin{array}{l}\mathrm{D} \\
\mathrm{mm}\end{array}$ & $\begin{array}{l}\text { B } \\
\mathrm{mm}\end{array}$ & $\begin{array}{l}\mathrm{D} \\
\mathrm{mm}\end{array}$ & $\begin{array}{l}\text { B } \\
\mathrm{mm}\end{array}$ & $\begin{array}{l}\mathrm{D} \\
\mathrm{mm}\end{array}$ \\
\hline $\begin{array}{l}\text { Har } \\
\text { d, } \\
\text { Med } \\
\text { ium, } \\
\text { soft }\end{array}$ & $\begin{array}{l}\text { Bea } \\
\mathrm{m}\end{array}$ & 230 & 450 & 230 & 500 & 300 & 550 \\
\cline { 2 - 8 } & $\begin{array}{l}\text { Colu } \\
\text { mn }\end{array}$ & 350 & 575 & 425 & 650 & 475 & 750 \\
\hline
\end{tabular}

*B = Width, $\mathrm{D}=$ Depth

Table 3: Parameters considered for dead load and live load

\begin{tabular}{|l|l|}
\hline Type of loading & Load \\
\hline Floor finish on slab & $1.50 \mathrm{kN} / \mathrm{m}^{2}$ \\
\hline Floor finish on Terrace & $2.00 \mathrm{kN} / \mathrm{m}^{2}$ \\
\hline Live load on Slab & $2.00 \mathrm{kN} / \mathrm{m}^{2}$ \\
\hline Live load on Terrace & $1.50 \mathrm{kN} / \mathrm{m}^{2}$ \\
\hline Peripheral wall & $11.73 \mathrm{kN} / \mathrm{m}^{2}$ \\
\hline Interior walls & $5.87 \mathrm{kN} / \mathrm{m}^{2}$ \\
\hline Parapet walls & $2.30 \mathrm{kN} / \mathrm{m}^{2}$ \\
\hline
\end{tabular}

The parameters assumed for earthquake loading as per IS1893 part-1 are given in Table 4. The parameters assumed for wind loading as per IS875 part-3 are given in Table 5. All buildings are designed as per the load combinations given in IS1893 part-1. The fundamental natural period of the buildings calculated using the formula as per IS1893 part- 1 is shown in Table 6 .

Table 4: Parameters considered for earthquake load

\begin{tabular}{|l|l|}
\hline Parameters & \\
\hline Seismic zone factor - Zone III & 0.16 \\
\hline Seismic zone factor - Zone V & 0.36 \\
\hline Importance factor & 1.0 \\
\hline Response reduction factor & 5.0 \\
\hline Seismic weight & DL+0.25 LL \\
\hline
\end{tabular}

Table 5: Parameters considered for wind load

\begin{tabular}{|l|l|}
\hline Parameters & \\
\hline Basic wind speed $\mathrm{V}_{\mathrm{b}}-$ Zone III & $39 \mathrm{~m} / \mathrm{s}$ \\
\hline Basic wind speed $\mathrm{V}_{\mathrm{b}}-$ Zone V & $50 \mathrm{~m} / \mathrm{s}$ \\
\hline Terrain category & 4 \\
\hline Building class & $\mathrm{B}$ \\
\hline Risk coefficient factor $-\mathrm{k}_{1}$ & 1.0 \\
\hline Topography factor & 1.0 \\
\hline
\end{tabular}




\subsection{Pushover Curve and Damage States}

SAP2000 [16] is used to prepare 3D model of buildings for the present study. Beams and columns are modeled using frame element. Material nonlinearity in terms of stress-strain relationship for concrete is introduced through Mander model and steel through Simple model in the numerical model of buildings.

Table 6: Time period T of buildings as per IS1893 part-1

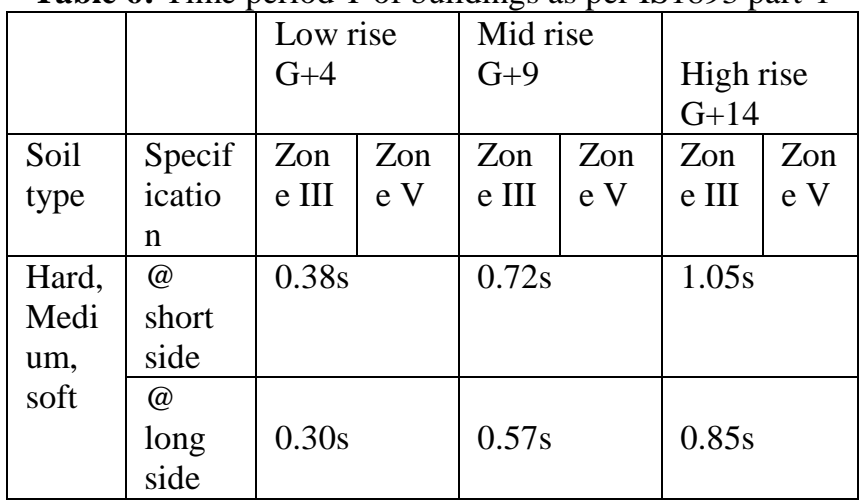

To perform pushover analysis, nonlinear hinges are assigned along the column length and to the beam. PM2M3 hinges are assigned to columns and M3 hinges in beams [17]. Nonlinear hinge properties of frame elements have been evaluated using section designer of the software and have been assigned to the numerical model. Nonlinear static pushover analysis (displacement controlled) is performed on the wharf to obtain its capacity curve. Incremental accelerating load in $\mathrm{X}$ direction is applied to the model, with initial stress condition as DL+0.25LL (Dead Load +0.25 Live Load).

The displacement is examined at roof top. Prior, modal analysis is performed to get the fundamental modal shape of the buildings. The fundamental modal time period of the buildings are given in Table 7, which has been used in the present study.

Table 7: Modal Time period T of buildings @ short side

\begin{tabular}{|l|l|l|l|l|l|l|}
\hline & \multicolumn{2}{l|l}{$\begin{array}{l}\text { Low rise } \\
\text { G+4 }\end{array}$} & \multicolumn{2}{l|}{$\begin{array}{l}\text { Mid rise } \\
\text { G+9 }\end{array}$} & \multicolumn{2}{l|}{$\begin{array}{l}\text { High rise } \\
\text { G+14 }\end{array}$} \\
\hline $\begin{array}{l}\text { Soil } \\
\text { type }\end{array}$ & $\begin{array}{l}\text { Zone } \\
\text { III }\end{array}$ & $\begin{array}{l}\text { Zone } \\
\text { V }\end{array}$ & $\begin{array}{l}\text { Zone } \\
\text { III }\end{array}$ & $\begin{array}{l}\text { Zone } \\
\text { V }\end{array}$ & $\begin{array}{l}\text { Zone } \\
\text { III }\end{array}$ & $\begin{array}{l}\text { Zone } \\
\text { V }\end{array}$ \\
\hline Hard & $0.86 \mathrm{~s}$ & $0.69 \mathrm{~s}$ & $1.17 \mathrm{~s}$ & $0.98 \mathrm{~s}$ & $1.85 \mathrm{~s}$ & $1.46 \mathrm{~s}$ \\
\hline Medium & $1.0 \mathrm{~s}$ & $0.84 \mathrm{~s}$ & $1.33 \mathrm{~s}$ & $1.12 \mathrm{~s}$ & $1.98 \mathrm{~s}$ & $1.54 \mathrm{~s}$ \\
\hline Soft & $1.0 \mathrm{~s}$ & $0.84 \mathrm{~s}$ & $1.33 \mathrm{~s}$ & $1.12 \mathrm{~s}$ & $1.98 \mathrm{~s}$ & $1.54 \mathrm{~s}$ \\
\hline
\end{tabular}

There are four damage states i.e. I, II, III and IV, related to serviceable, repairable, near collapse and collapse levels of a wharf structure. At serviceable level, the structure continues to function with minor or no structural damage. At repairable level, the structural damage is controllable and repairable. At near-collapse level, the structural damage is substantial. At collapse level, the structural strength is completely lost. Hence upper bounds of the damage states I, II and III are based on the sequence of plasticity development during the pushover process.

I is the state where a column initially cracks. III is the state where a column section reaches its ultimate state. II is the state taken as average of I and III. The damage states obtained are shown in Table 8 and 9.

Table 8: Damage states as per hinge formation sequence, Zone III

\begin{tabular}{|l|l|l|l|l|}
\hline & & \multicolumn{3}{|l|}{ Drift (\%) } \\
\hline $\begin{array}{l}\text { Soil } \\
\text { type }\end{array}$ & $\begin{array}{l}\text { Building } \\
\text { type }\end{array}$ & $\begin{array}{l}\text { Damage } \\
\text { State I }\end{array}$ & $\begin{array}{l}\text { Damage } \\
\text { State II }\end{array}$ & $\begin{array}{l}\text { Damage } \\
\text { State III }\end{array}$ \\
\hline \multirow{4}{*}{ Hard } & Low rise & 0.19 & 0.52 & 0.85 \\
\cline { 2 - 5 } & Mid rise & 0.27 & 0.39 & 0.66 \\
\cline { 2 - 5 } & $\begin{array}{l}\text { High } \\
\text { rise }\end{array}$ & 0.49 & 1.12 & 1.74 \\
\hline \multirow{5}{*}{ Sedium } & Low rise & 0.38 & 0.63 & 0.88 \\
\cline { 2 - 5 } & Mid rise & 0.24 & 0.36 & 0.48 \\
\cline { 2 - 5 } & $\begin{array}{l}\text { High } \\
\text { rise }\end{array}$ & 0.64 & 1.21 & 1.79 \\
\hline \multirow{5}{*}{ Soft } & Low rise & 0.38 & 0.63 & 0.88 \\
\cline { 2 - 5 } & Mid rise & 0.24 & 0.36 & 0.48 \\
\cline { 2 - 5 } & $\begin{array}{l}\text { High } \\
\text { rise }\end{array}$ & 0.64 & 1.21 & 1.79 \\
\hline
\end{tabular}

Table 9: Damage states as per hinge formation sequence,

\begin{tabular}{|l|l|l|l|l|}
\hline \multicolumn{5}{|c|}{ Zone V } \\
\hline \multirow{4}{*}{$\begin{array}{l}\text { Soil } \\
\text { type }\end{array}$} & $\begin{array}{l}\text { Building } \\
\text { type }\end{array}$ & $\begin{array}{l}\text { Damage } \\
\text { State I }\end{array}$ & $\begin{array}{l}\text { Damage } \\
\text { State II }\end{array}$ & $\begin{array}{l}\text { Damage } \\
\text { State III }\end{array}$ \\
\hline \multirow{4}{*}{ Hard } & Low rise & 0.19 & 0.39 & 0.59 \\
\cline { 2 - 5 } & Mid rise & 0.27 & 0.60 & 0.93 \\
\cline { 2 - 5 } & $\begin{array}{l}\text { High } \\
\text { rise }\end{array}$ & 0.34 & 0.80 & 1.26 \\
\hline \multirow{5}{*}{ Sedium } & Low rise & 0.39 & 0.57 & 0.75 \\
\cline { 2 - 5 } & Mid rise & 0.22 & 0.41 & 0.60 \\
\cline { 2 - 5 } & $\begin{array}{l}\text { High } \\
\text { rise }\end{array}$ & 0.30 & 0.49 & 0.69 \\
\hline \multirow{5}{*}{ Soft } & Low rise & 0.39 & 0.57 & 0.75 \\
\cline { 2 - 5 } & Mid rise & 0.22 & 0.41 & 0.60 \\
\cline { 2 - 5 } & $\begin{array}{l}\text { High } \\
\text { rise }\end{array}$ & 0.30 & 0.49 & 0.69 \\
\hline
\end{tabular}

Similarly, HAZUS MH 2.0 has also defined damage states to typical building stocks for different seismic zones due to ground shaking as shown in Table 10 and 11.

Table 10: Damage states as per HAZUS MH 2.0, Zone III

\begin{tabular}{|l|l|l|l|}
\hline \multirow{2}{*}{$\begin{array}{l}\text { Building } \\
\text { Type }\end{array}$} & \multicolumn{2}{|l|}{ Drift (\%) } \\
\cline { 2 - 4 } & $\begin{array}{l}\text { Damage } \\
\text { State I }\end{array}$ & $\begin{array}{l}\text { Damage } \\
\text { State II }\end{array}$ & $\begin{array}{l}\text { Damage } \\
\text { State III }\end{array}$ \\
\hline Low rise & 0.50 & 0.84 & 2.22 \\
\hline Mid rise & 0.33 & 0.56 & 1.48 \\
\hline High rise & 0.25 & 0.42 & 1.11 \\
\hline
\end{tabular}


Table 11: Damage states as per HAZUS MH 2.0, Zone V

\begin{tabular}{|l|l|l|l|}
\hline \multirow{2}{*}{$\begin{array}{l}\text { Building } \\
\text { Type }\end{array}$} & Drift (\%) & \multicolumn{3}{|c|}{$\begin{array}{l}\text { Damage } \\
\text { State I }\end{array}$} & $\begin{array}{l}\text { Damage } \\
\text { State II }\end{array}$ & $\begin{array}{l}\text { Damage } \\
\text { State III }\end{array}$ \\
\hline Low rise & 0.50 & 0.97 & 2.86 \\
\hline Mid rise & 0.33 & 0.65 & 1.91 \\
\hline High rise & 0.25 & 0.48 & 1.43 \\
\hline
\end{tabular}

\subsection{Demand Spectra and Ground Motions}

The default 5\% spectra for Design Based Earthquake (DBE) for all soil types as per IS1893 part-1 are shown in figure 5 and 6. The soil type available in Gujarat region has SPT value in the range of 15-50 for hard and medium soils and less than 15 soft soils. As per International Building Code, such hard and medium soils are classified as "Type D" and soft soils as "Type E"; with varying average shear wave velocity from $180-370 \mathrm{~m} / \mathrm{s}$ and $0-179 \mathrm{~m} / \mathrm{s}$ [18].

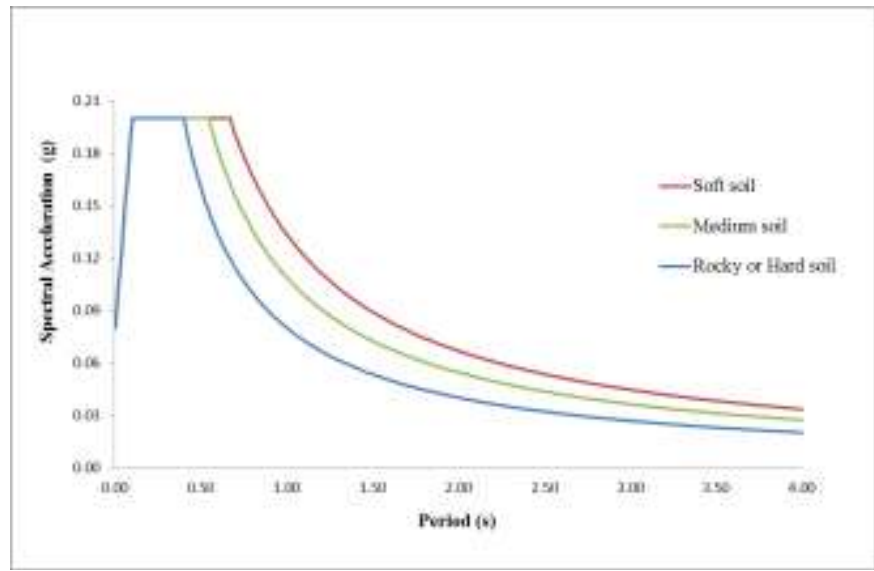

Fig - 5: Response spectra for all soil types, 5\% damping, DBE, zone III

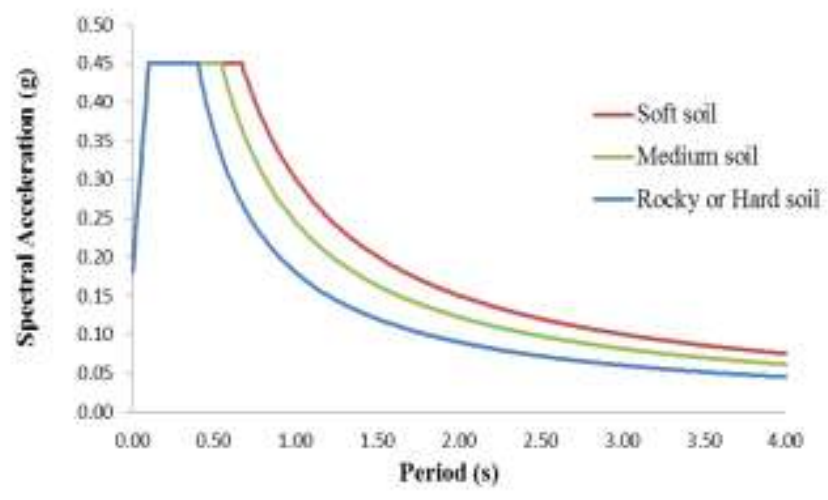

Fig - 6: Response spectra for all soil types, 5\% damping, DBE, zone V

Based on geological features, Gujarat is divided into three parts namely Kutch region, Saurashtra region and Mainland Gujarat [19]. Kutch region (zone V), has witnessed high rate of recurrence of large earthquakes and low rate of recurrence of moderate earthquakes [20]. Kutch region records several large damaging earthquakes in the magnitude of 6 to 8 ranging over the last several hundred years, making Kutch one of the active seismic regions. The major faults of the Kutch region are Allah Bund Fault, Island Belt Fault, Kutch Mainland fault (KMF) and Katrol Hill fault (KHF). The fault mechanism observed in Kutch region is mostly reverse/ reverse oblique. Mainland Gujarat (zone III) records moderate seismicity (magnitude of 4 to 6) in comparison to Kutch region, encompassing two main faults namely Cambay rift zone and Narmada rift zone. There is no specific fault mechanism observed in mainland Gujarat.

Due to lack of availability of past earthquake records for the selected zone sites in Gujarat, 5 pairs of earthquake records are obtained from PEER ground motion database [21], having similar topographical features, soil conditions, magnitude, fault type and distance from source of earthquake. PEER database offers automated scaling according to the response spectra uploaded.

\subsection{Capacity Spectrum Method and Fragility} Analysis

Capacity Spectrum Method (CSM) is used to obtain the response of the buildings. CSM is a non- linear static analysis, proposed by ATC-40 for the seismic evaluation and retrofit of buildings. The buildings are classified as Type A for hysteresis damping model as the buildings are newly designed with effective lateral load resisting system. In CSM, the ground motions are transformed into demand spectrum and the capacity curve of building is transformed into capacity spectrum, plotted in an acceleration $\mathrm{v} / \mathrm{s}$ displacement domain. The maximum response of building to the given earthquake event is obtained by the intersection point of the demand spectrum with capacity spectrum, known as performance point. Seismic response of building is obtained in terms of displacement. For fragility analysis, ground intensity measure is represented in the form of PGA. The selected earthquake events are normalized and scaled from $0.1 \mathrm{~g}$ to $1.0 \mathrm{~g}$ (10 PGA levels) so as to get a response matrix. Damage states and response matrix of a mid-rise building in hard soil and zone $\mathrm{V}$ as per hinge formation sequence and HAZUS are shown in table 12, table 13, table 14 and table 15 .

According to the displacement bound of each defined damage state, the fragility curve for the damage state $S_{i}$ is the conditional probability that the building has a state of damage exceeding the damage state $S_{i}$ at a specific PGA level, as shown below:

$P[S>s \mid P G A]=P\left[X>x_{i} \mid P G A\right]$

$=1-\phi\left[\left(\ln \left(x_{i}\right)-\lambda\right) / s\right](2)$

where, $\Phi($.$) is the standard normal cumulative distribution$ function, $x_{i}$ is the upper bound for $S_{i}(i=I, I I, I I I)$, and $\lambda$ and $\zeta$ are the two parameters of the lognormal distribution of the 
random displacement variable $\mathrm{x}$, which can be calculated from other two parameters of the normal distribution: the mean $(\mu)$ and the standard deviation $(\sigma)$ as shown below:

$$
\begin{aligned}
& \lambda=\ln \mu-1 / 2 \varsigma^{2}(3) \\
& \varsigma^{2}=\ln \left[1+\delta^{2}\right]
\end{aligned}
$$

where, $\delta$ is $\sigma / \mu$.

Table 12: Damage states for mid-rise building with hard soil, as per hinge formation sequence, Zone $\mathrm{V}$

\begin{tabular}{|l|l|l|l|l|l|}
\hline Damage State & & I & II & III \\
\hline Displacement Bound $\mathrm{x}_{\mathrm{i}}(\mathrm{m})$ & & 0.086 & 0.192 & 0.298 \\
\hline
\end{tabular}

\begin{tabular}{|c|c|c|c|c|c|c|c|c|c|c|}
\hline \multirow[t]{3}{*}{ EQ Event } & \multicolumn{10}{|c|}{ DISPLACEMENT (m) } \\
\hline & \multicolumn{10}{|c|}{ PGA (g) } \\
\hline & 0.1 & 0.2 & 0.3 & 0.4 & 0.5 & 0.6 & 0.7 & 0.8 & 0.9 & 1 \\
\hline EQ1 & 0.04 & 0.08 & 0.12 & 0.19 & 0.24 & 0.28 & - & - & - & - \\
\hline EQ2 & 0.06 & 0.09 & 0.12 & 0.14 & 0.17 & - & - & - & - & - \\
\hline EQ3 & 0.04 & 0.09 & 0.13 & 0.17 & 0.22 & 0.26 & 0.30 & - & - & - \\
\hline EQ4 & 0.04 & 0.09 & 0.12 & 0.15 & 0.18 & 0.21 & 0.24 & 0.27 & - & - \\
\hline EQ5 & 0.03 & 0.08 & 0.12 & 0.15 & 0.20 & 0.24 & 0.29 & - & - & - \\
\hline EQ6 & 0.03 & 0.05 & 0.08 & 0.11 & 0.15 & 0.18 & 0.21 & 0.23 & 0.25 & 0.27 \\
\hline EQ7 & 0.03 & 0.05 & 0.08 & 0.10 & 0.15 & 0.20 & 0.24 & 0.27 & - & - \\
\hline EQ8 & 0.03 & 0.08 & 0.11 & 0.13 & 0.15 & 0.17 & 0.20 & 0.22 & 0.25 & 0.27 \\
\hline EQ9 & 0.05 & 0.08 & 0.10 & 0.11 & 0.13 & 0.14 & 0.15 & 0.16 & 0.18 & 0.20 \\
\hline EQ10 & 0.03 & 0.06 & 0.09 & 0.12 & 0.14 & 0.17 & 0.21 & 0.24 & - & - \\
\hline
\end{tabular}

Table 13: Response matrix for mid-rise building with hard soil, as per hinge formation sequence, Zone V

Table 14: Damage states for mid-rise building with hard soil, as per HAZUS, Zone V

\begin{tabular}{|l|l|l|l|l|l|}
\hline Damage State & & & I & II & III \\
\hline Displacement Bound $\mathrm{x}_{\mathrm{i}}(\mathrm{m})$ & & 0.105 & 0.208 & 0.611 \\
\hline
\end{tabular}

\begin{tabular}{|c|c|c|c|c|c|c|c|c|c|c|}
\hline \multirow[t]{3}{*}{ EQ Event } & \multicolumn{10}{|c|}{ DISPLACEMENT (m) } \\
\hline & \multicolumn{10}{|c|}{ PGA (g) } \\
\hline & 0.1 & 0.2 & 0.3 & 0.4 & 0.5 & 0.6 & 0.7 & 0.8 & 0.9 & 1 \\
\hline EQ1 & 0.04 & 0.08 & 0.12 & 0.19 & 0.24 & 0.28 & - & - & - & - \\
\hline EQ2 & 0.06 & 0.09 & 0.12 & 0.14 & 0.17 & - & - & - & - & - \\
\hline EQ3 & 0.04 & 0.09 & 0.13 & 0.17 & 0.22 & 0.26 & 0.30 & - & - & - \\
\hline EQ4 & 0.04 & 0.09 & 0.12 & 0.15 & 0.18 & 0.21 & 0.24 & 0.27 & - & - \\
\hline EQ5 & 0.03 & 0.08 & 0.12 & 0.15 & 0.20 & 0.24 & 0.29 & - & - & - \\
\hline EQ6 & 0.03 & 0.05 & 0.08 & 0.11 & 0.15 & 0.18 & 0.21 & 0.23 & 0.25 & 0.27 \\
\hline EQ7 & 0.03 & 0.05 & 0.08 & 0.10 & 0.15 & 0.20 & 0.24 & 0.27 & - & - \\
\hline EQ8 & 0.03 & 0.08 & 0.11 & 0.13 & 0.15 & 0.17 & 0.20 & 0.22 & 0.25 & 0.27 \\
\hline EQ9 & 0.05 & 0.08 & 0.10 & 0.11 & 0.13 & 0.14 & 0.15 & 0.16 & 0.18 & 0.20 \\
\hline EQ10 & 0.03 & 0.06 & 0.09 & 0.12 & 0.14 & 0.17 & 0.21 & 0.24 & - & - \\
\hline
\end{tabular}

Table 15: Response matrix for mid-rise building with hard soil, as per HAZUS, Zone V

\section{RESULTS AND DISCUSSIONS}

Typical fragility curves derived for all buildings in zone $\mathrm{V}$ as per hinge formation sequence and HAZUS are shown from figure 7 to figure 24. The summary of probability of failure of buildings for zone III and zone V, using hinge formation sequence and HAZUS is shown in table 16, table 17 , table 18 and table 19. 


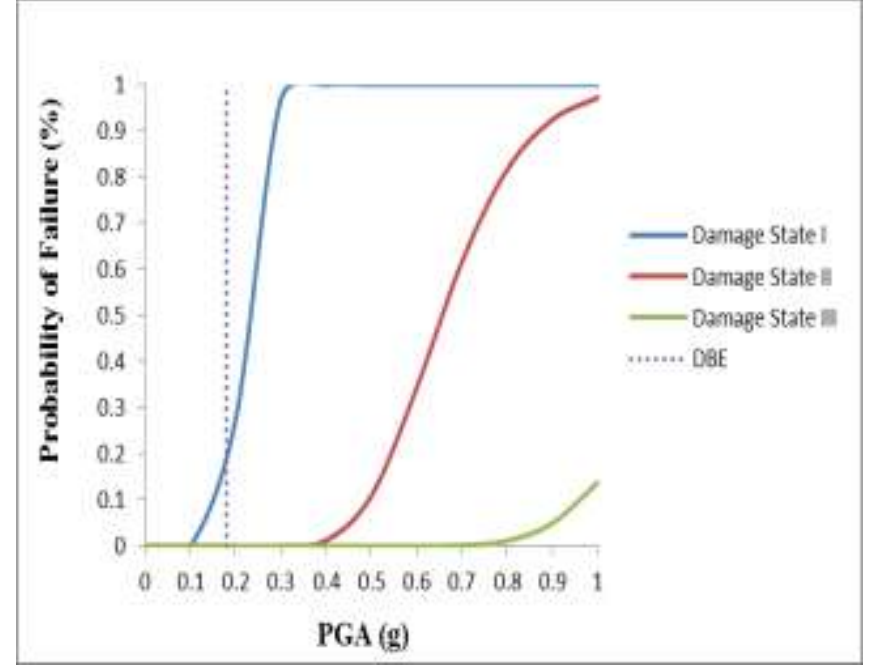

Fig - 7: Fragility curves, low-rise building, hard soil, as per hinge formation sequence, zone $\mathrm{V}$

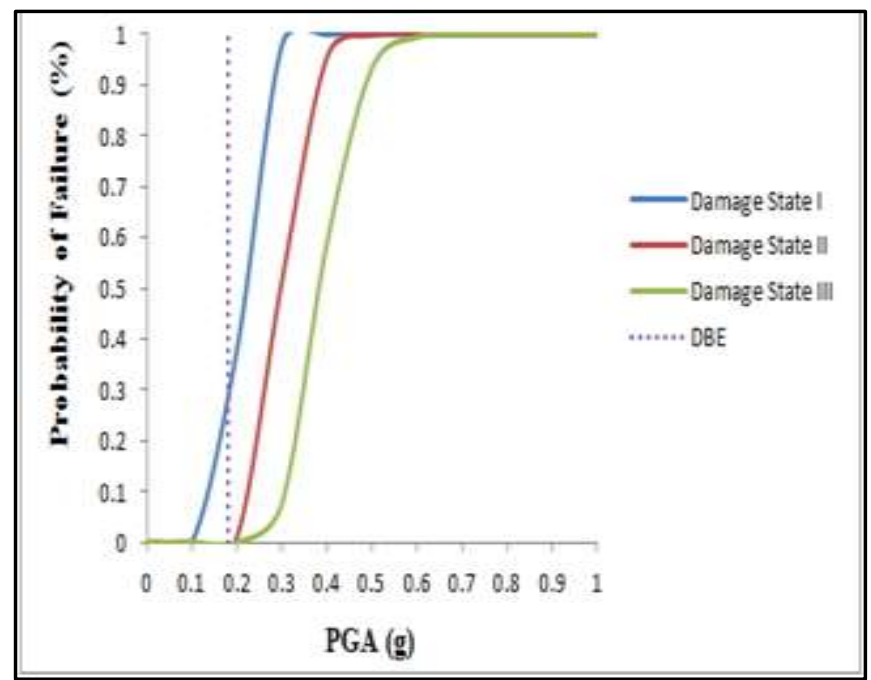

Fig - 8: Fragility curves, low-rise building, medium soil, as per hinge formation sequence, zone $\mathrm{V}$

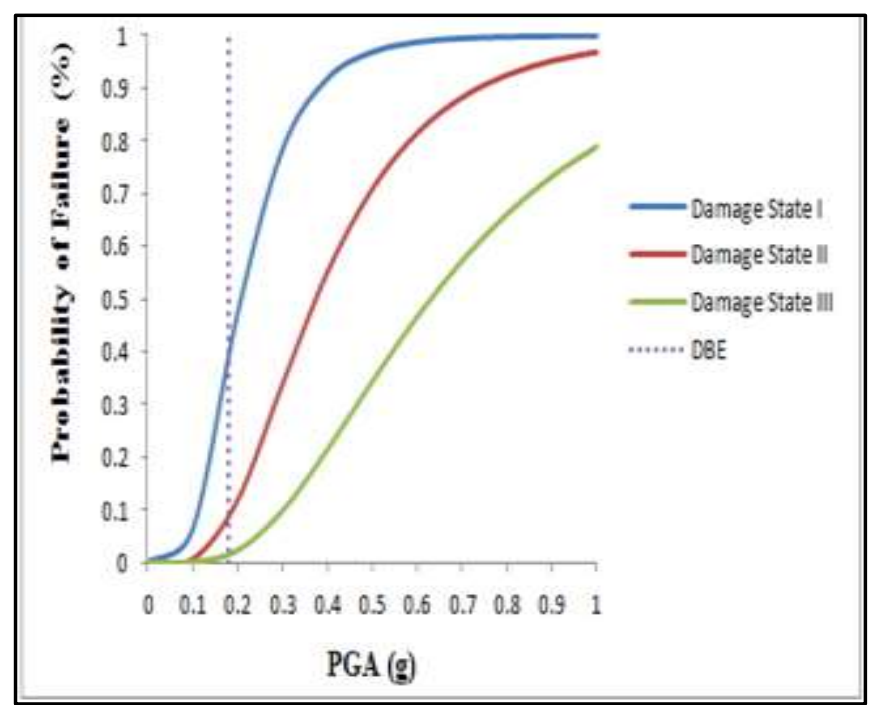

Fig - 9: Fragility curves, low-rise building, soft soil, as per hinge formation sequence, zone $\mathrm{V}$

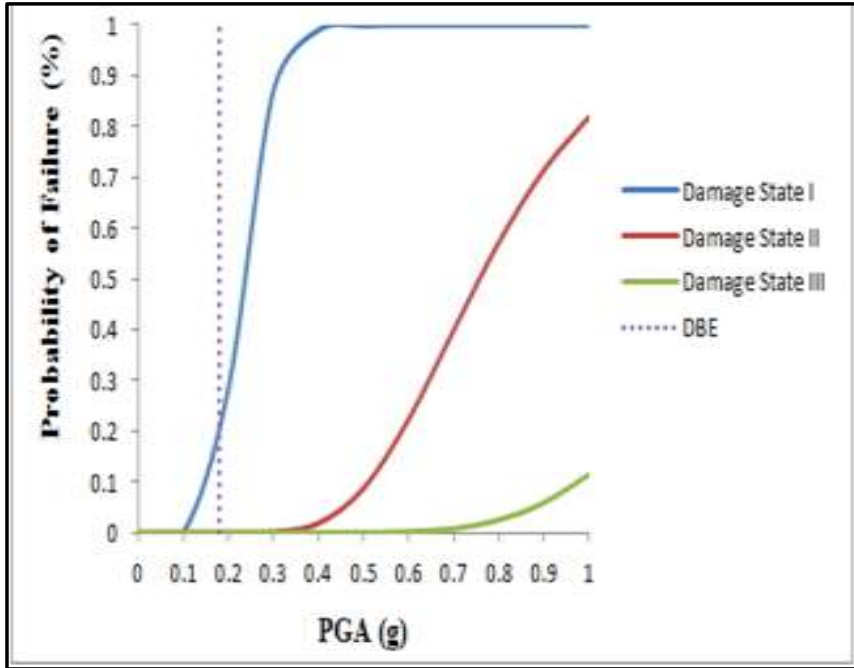

Fig - 10: Fragility curves, mid-rise building, hard soil, as per hinge formation sequence, zone $\mathrm{V}$

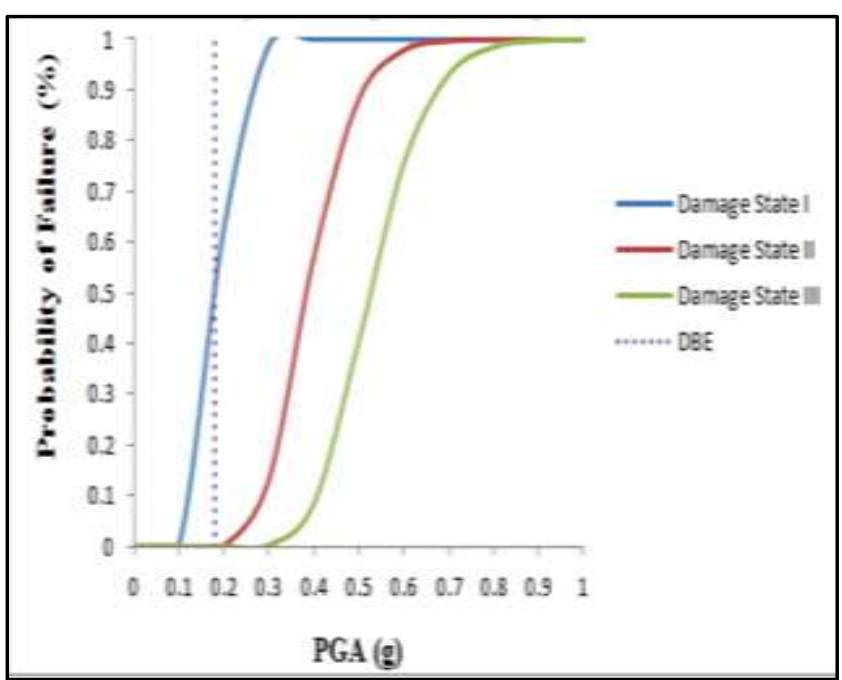

Fig - 11: Fragility curves, mid-rise building, medium soil, as per hinge formation sequence, zone $\mathrm{V}$

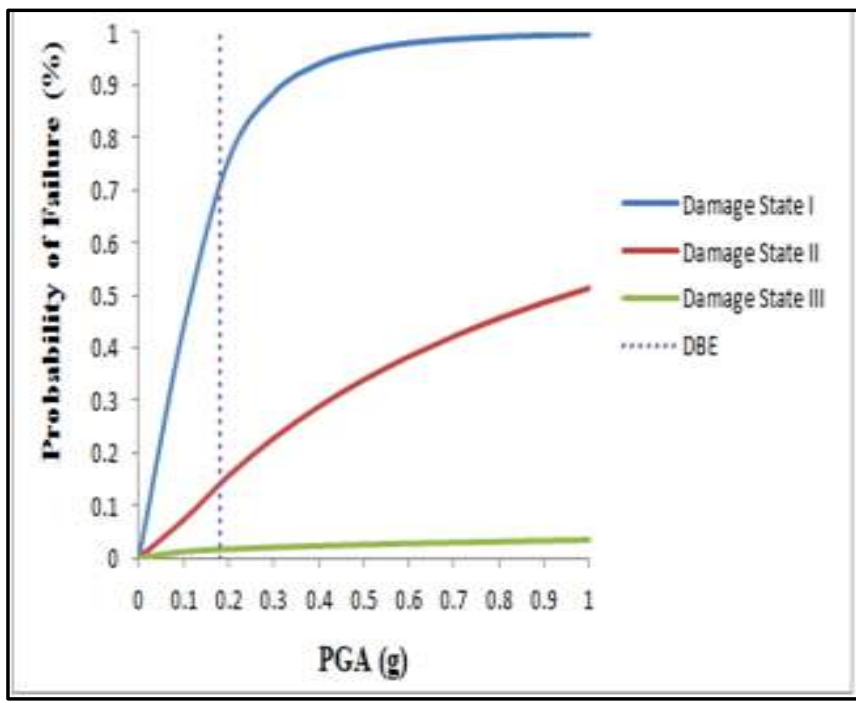

Fig - 12: Fragility curves, mid-rise building, soft soil, as per hinge formation sequence, zone $\mathrm{V}$ 


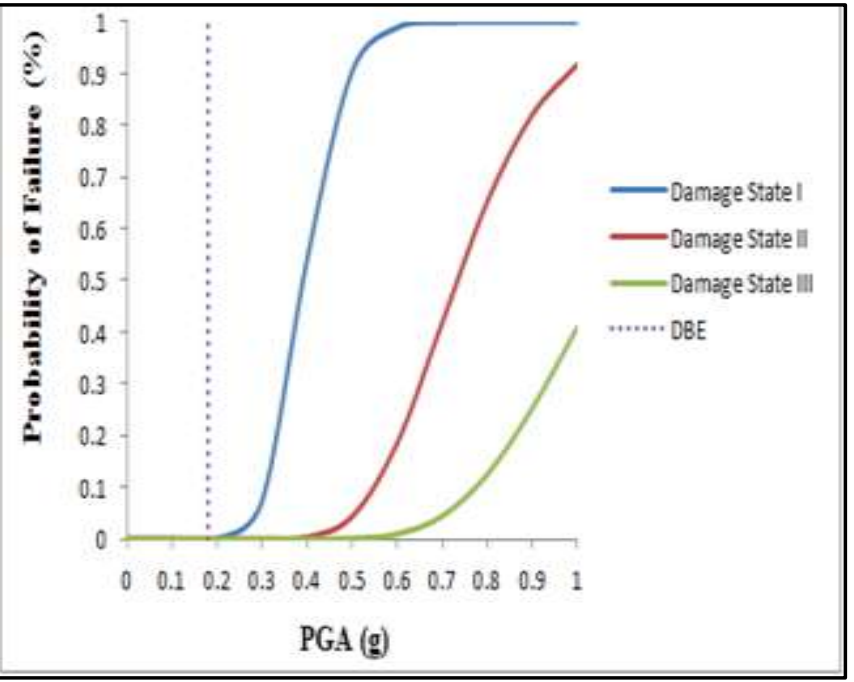

Fig - 13: Fragility curves, high-rise building, hard soil, as per hinge formation sequence, zone $\mathrm{V}$

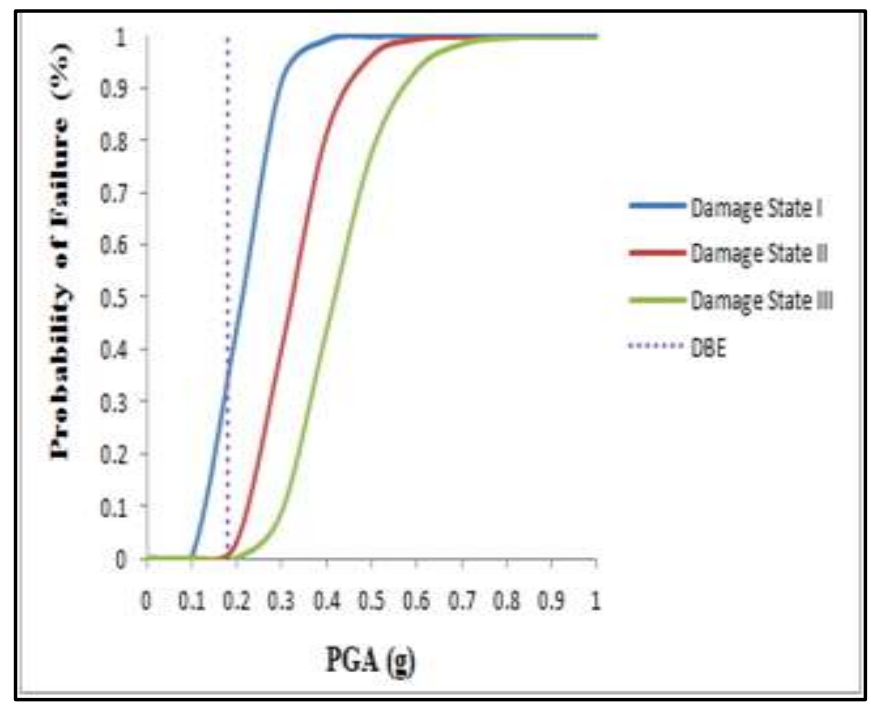

Fig - 14: Fragility curves, high-rise building, medium soil, as per hinge formation sequence, zone $\mathrm{V}$

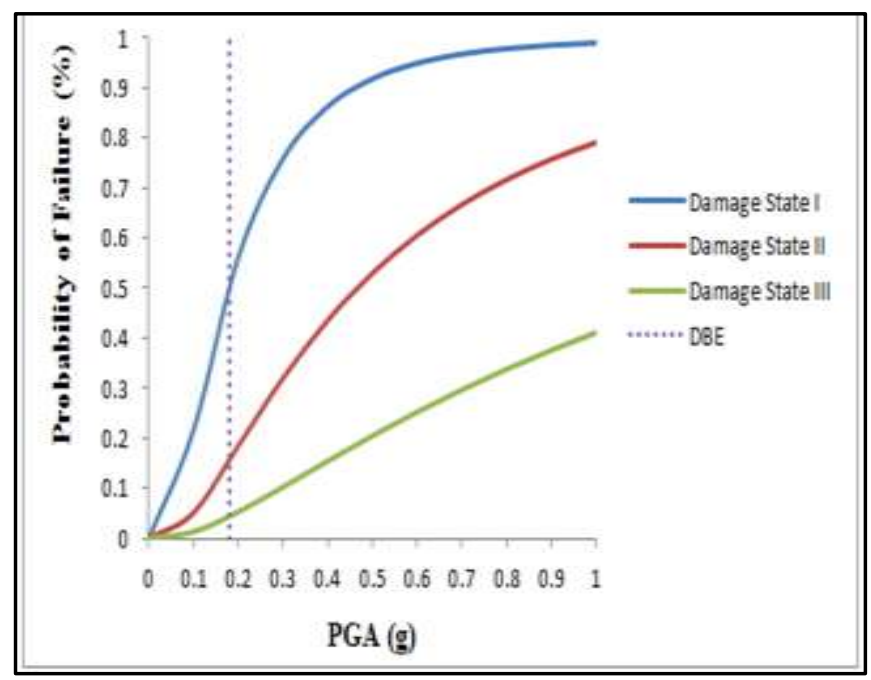

Fig - 15: Fragility curves, high-rise building, soft soil, as per hinge formation sequence, zone $\mathrm{V}$

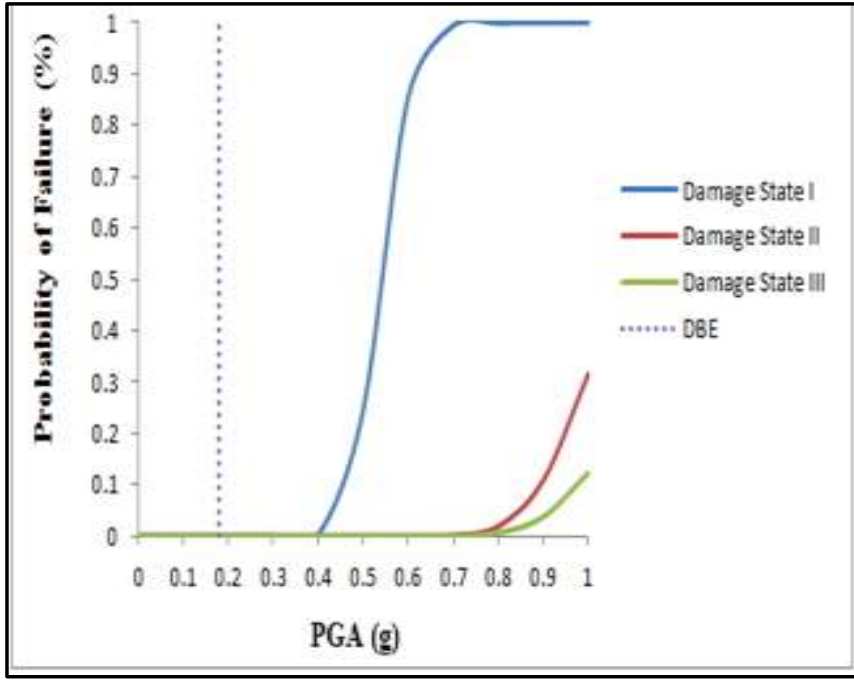

Fig - 16: Fragility curves, low-rise building, hard soil, as per HAZUS, zone V

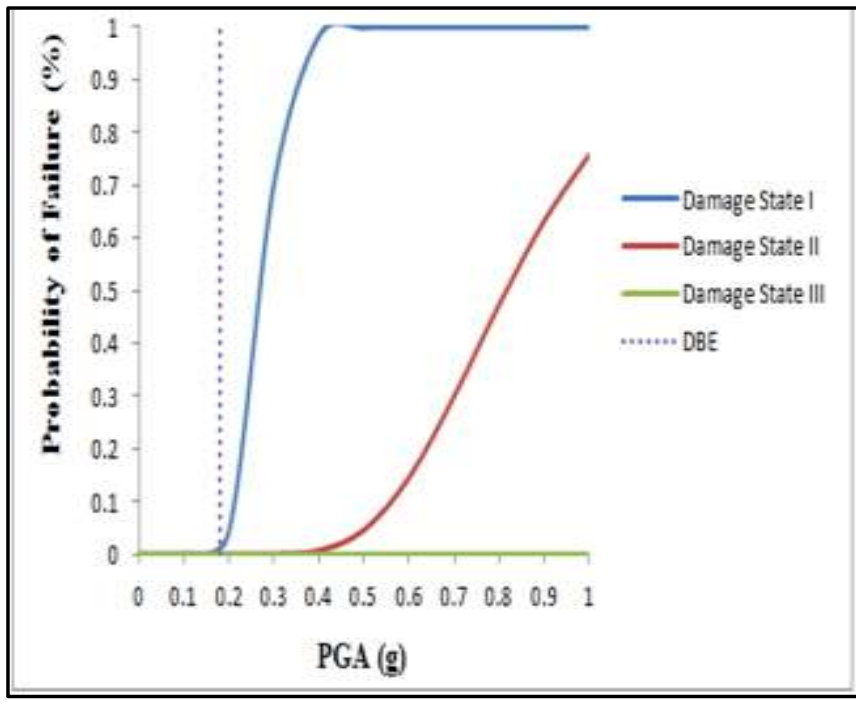

Fig - 17: Fragility curves, low-rise building, medium soil, as per HAZUS, zone $\mathrm{V}$

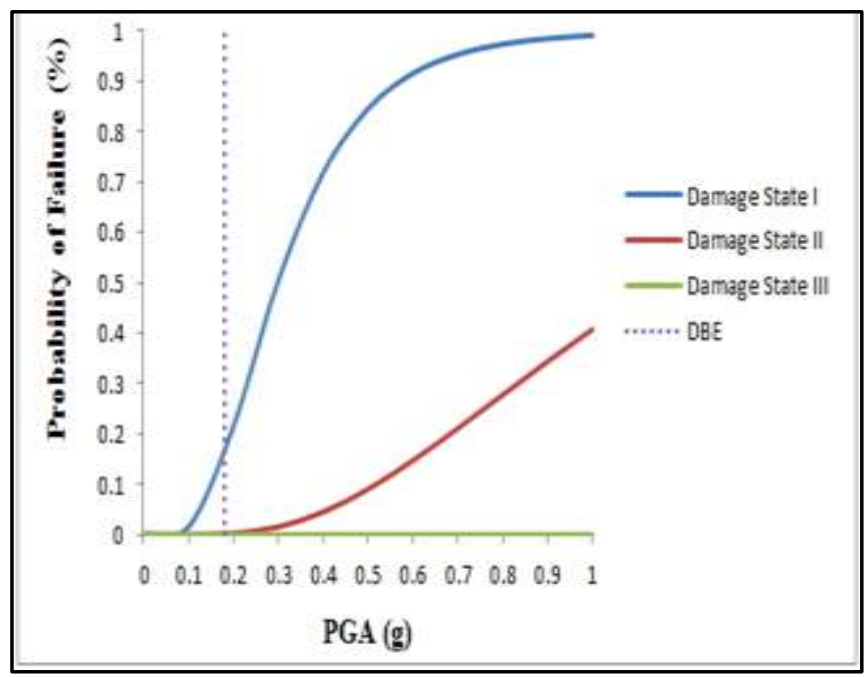

Fig - 18: Fragility curves, low-rise building, soft soil, as per HAZUS, zone V 


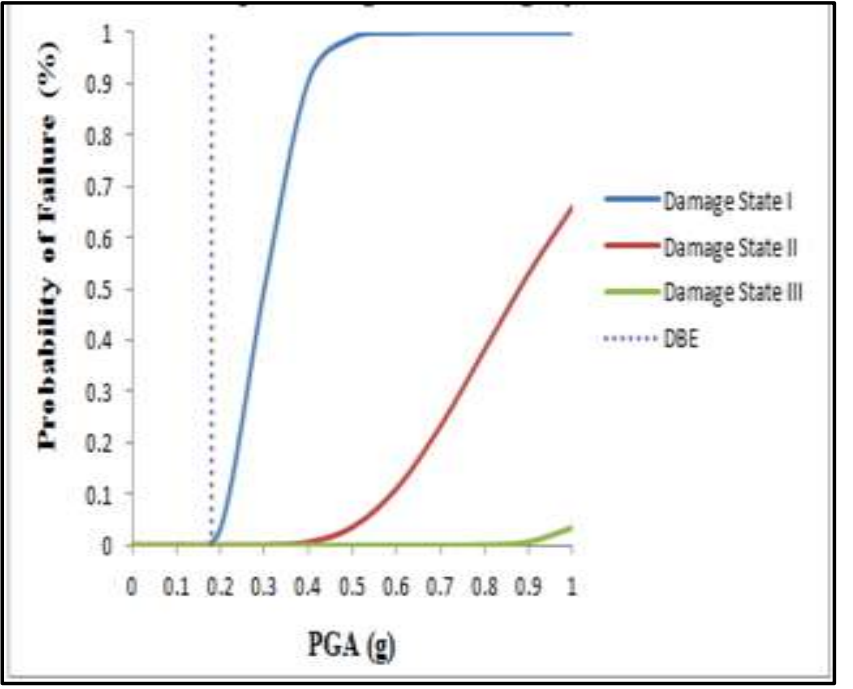

Fig - 19: Fragility curves, mid-rise building, hard soil, as per HAZUS, zone V

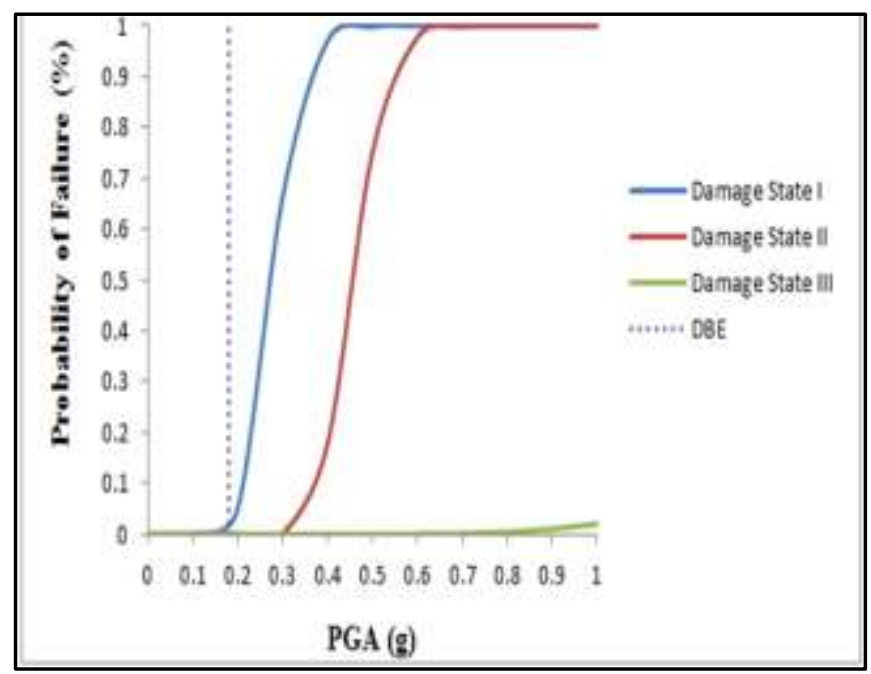

Fig - 20: Fragility curves, mid-rise building, medium soil, as per HAZUS, zone $\mathrm{V}$

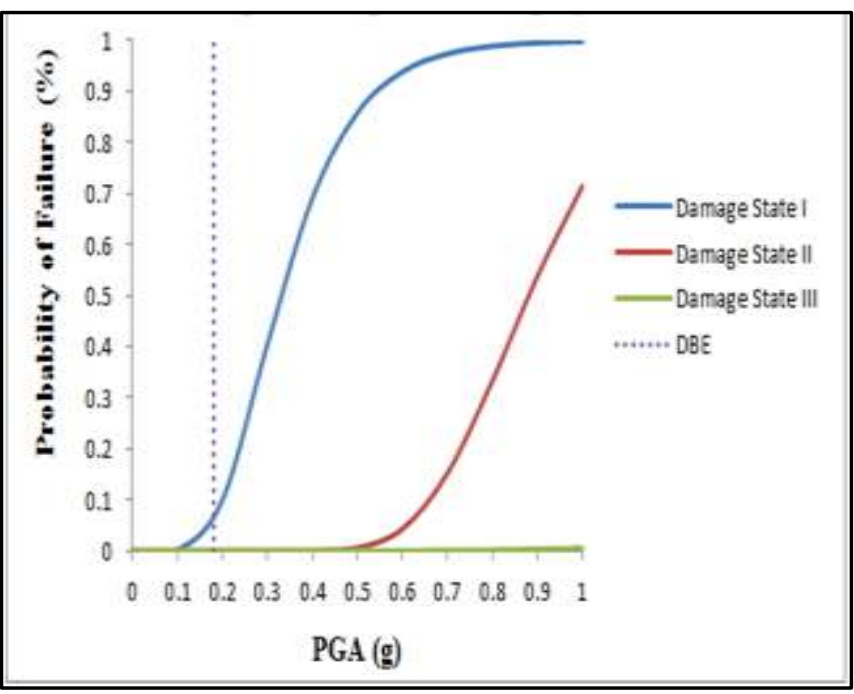

Fig - 21: Fragility curves, mid-rise building, soft soil, as per HAZUS, zone $\mathrm{V}$

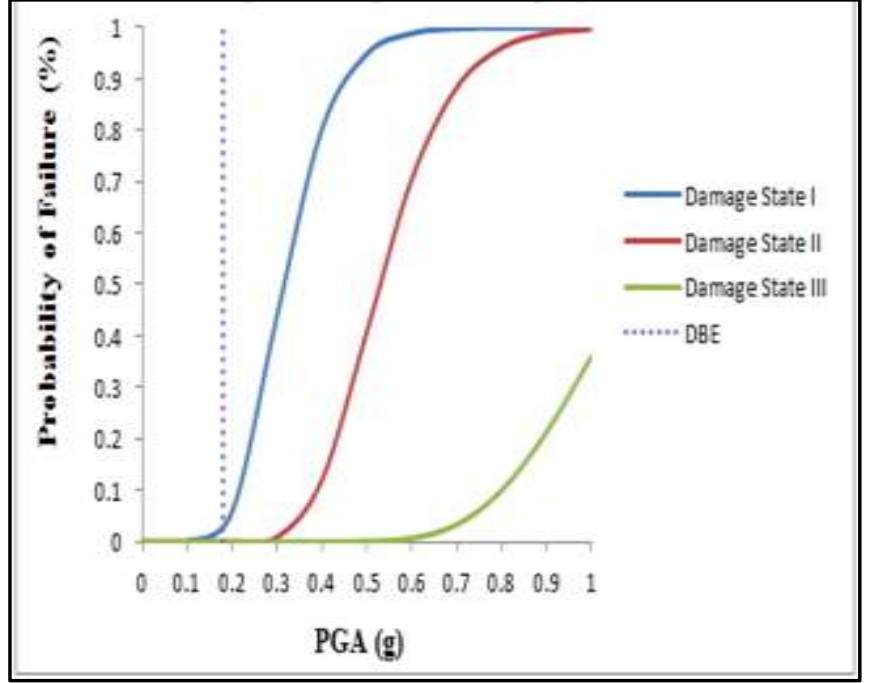

Fig - 22: Fragility curves, high-rise building, hard soil, as per HAZUS, zone $\mathrm{V}$

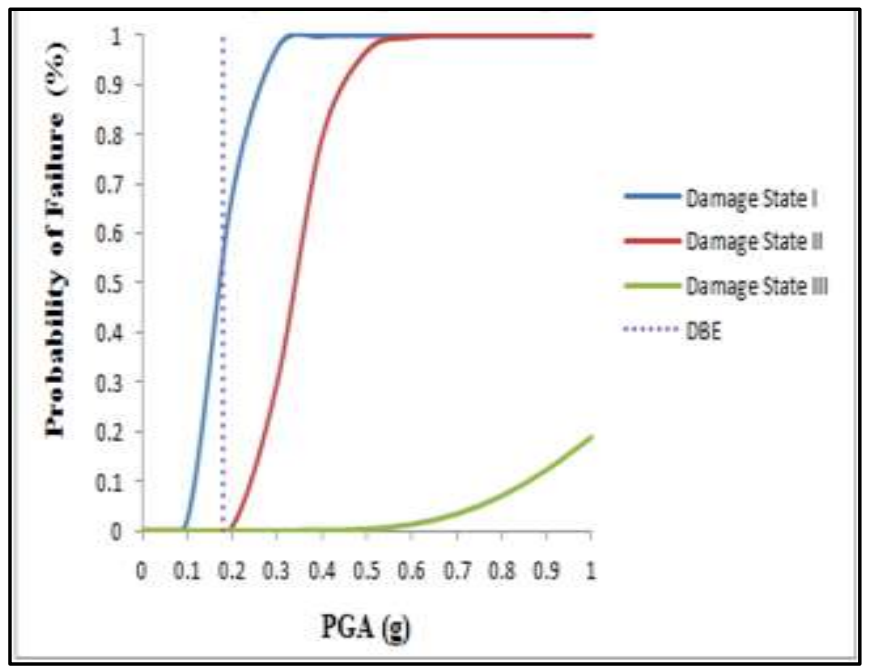

Fig - 23: Fragility curves, high-rise building, medium soil, as per HAZUS, zone $\mathrm{V}$

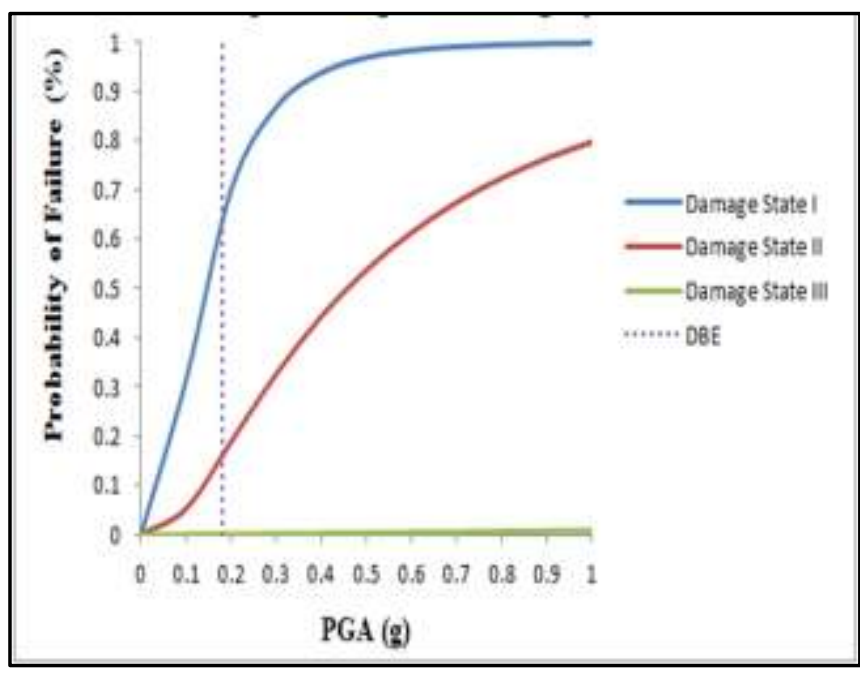

Fig - 24: Fragility curves, high-rise building, soft soil, as per HAZUS, zone $\mathrm{V}$ 
Table 15: Probability of failure of buildings as per hinge formation sequence, zone III

\begin{tabular}{|l|l|l|l|l|}
\hline Building type & Soil type & Repairable (\%) & Near Collapse (\%) & $\begin{array}{l}\text { Collapse } \\
(\%)\end{array}$ \\
\hline \multirow{4}{*}{ Low-rise } & Hard & 0 & 0 & 0 \\
\cline { 2 - 5 } & Medium & 0 & 0 & 0 \\
\cline { 2 - 5 } & Soft & 2.11 & 0.26 & 0.05 \\
\hline \multirow{4}{*}{ Mid-rise } & Hard & 0.03 & 0 & 0 \\
\cline { 2 - 5 } & Medium & 1.62 & 0 & 0 \\
\cline { 2 - 5 } & Soft & 4.03 & 0.62 & 0.23 \\
\hline \multirow{5}{*}{ High-rise } & Hard & 0 & 0 & 0 \\
\cline { 2 - 5 } & Medium & 0 & 0 & 0 \\
\cline { 2 - 5 } & Soft & 0.01 & 0 & 0 \\
\hline
\end{tabular}

Table 16: Probability of failure of buildings as HAZUS, zone III

\begin{tabular}{|l|l|l|l|l|}
\hline Building type & Soil type & Repairable (\%) & Near Collapse (\%) & $\begin{array}{l}\text { Collapse } \\
(\%)\end{array}$ \\
\hline \multirow{3}{*}{ Low-rise } & Hard & 0 & 0 & 0 \\
\cline { 2 - 5 } & Medium & 0 & 0 & 0 \\
\cline { 2 - 5 } & Soft & 0.8 & 0.07 & 0 \\
\hline \multirow{2}{*}{ Mid-rise } & Hard & 0 & 0 & 0 \\
\cline { 2 - 5 } & Medium & 0 & 0 & 0 \\
\cline { 2 - 5 } & Soft & 1.19 & 0.11 & 0 \\
\hline \multirow{2}{*}{ High-rise } & Hard & 0 & 0 & 0 \\
\cline { 2 - 5 } & Medium & 0.67 & 0 & 0 \\
\cline { 2 - 5 } & Soft & 0.74 & 0.08 & 0 \\
\hline
\end{tabular}

Table 17: Probability of failure of buildings as per hinge formation sequence, zone V

\begin{tabular}{|l|l|l|l|l|}
\hline Building type & Soil type & Repairable (\%) & Near Collapse (\%) & $\begin{array}{l}\text { Collapse } \\
(\%)\end{array}$ \\
\hline \multirow{4}{*}{ Low-rise } & Hard & 21.79 & 0 & 0 \\
\cline { 2 - 5 } & Medium & 30.38 & 0.86 & 0.01 \\
\cline { 2 - 5 } & Soft & 39.08 & 9.57 & 1.84 \\
\hline \multirow{3}{*}{ Mid-rise } & Hard & 22.67 & 0 & 0 \\
\cline { 2 - 5 } & Medium & 50.08 & 0.12 & 0 \\
\cline { 2 - 5 } & Soft & 69.57 & 13.99 & 1.57 \\
\hline \multirow{3}{*}{ High-rise } & Hard & 0.01 & 0 & 0 \\
\cline { 2 - 5 } & Medium & 35.22 & 2.53 & 0.1 \\
\cline { 2 - 5 } & Soft & 49.24 & 15.81 & 4.51 \\
\hline
\end{tabular}

Table 18: Probability of failure of buildings as HAZUS, zone V

\begin{tabular}{|l|l|l|l|l|}
\hline Building type & Soil type & Repairable (\%) & Near Collapse (\%) & $\begin{array}{l}\text { Collapse } \\
(\%)\end{array}$ \\
\hline \multirow{4}{*}{ Low-rise } & Hard & 0 & 0 & 0 \\
\cline { 2 - 5 } & Medium & 3.46 & 0 & 0 \\
\cline { 2 - 5 } & Soft & 17.58 & 0.21 & 0 \\
\hline \multirow{4}{*}{ Mid-rise } & Hard & 2.61 & 0 & 0 \\
\cline { 2 - 5 } & Medium & 3.99 & 0 & 0 \\
\cline { 2 - 5 } & Soft & 8.03 & 0 & 0 \\
\hline \multirow{3}{*}{ High-rise } & Hard & 4.63 & 0 & 0 \\
\cline { 2 - 5 } & Medium & 54.27 & 0.6 & 0 \\
\cline { 2 - 5 } & Soft & 62.3 & 16.15 & 0.07 \\
\hline
\end{tabular}




\section{CONCLUSION}

- $\quad$ The time period of the buildings calculated as per IS1893 part-1, vary greatly from the modal time period obtained in the software. The variation for low-rise buildings is in the range of $80 \%-165 \%$. For mid-rise buildings, the variation is in the range of $36 \%-85 \%$. For high-rise buildings, the variation is in between $39 \%-89 \%$. IS1893 thus overestimates the seismic forces.

- The probability of damage of buildings for repairable (II), near collapse (III) and collapse (IV) damage states increases as we shift from the hard soil to medium soil and soft soil, respectively. Hence, repairing cost and damage to structure is highest in buildings situated on soft soil, following medium soil and hard soil.

- In zone III, as per the hinge formation sequence, the probability of damage of building for repairable (II), near collapse (III) and collapse (IV) damage state in hard soil, medium soil and soft soil increases as we shift from the low-rise to mid-rise and further decreases from mid-rise to high-rise buildings.

- In zone V, as per the hinge formation sequence, the probability of damage of building for repairable (II) damage state in hard soil, medium soil and soft soil increases as we shift from the low-rise to mid-rise and further decreases from mid-rise to high-rise buildings. The probability of damage to building for near collapse (III) and collapse (IV) damage states in medium soil decreases as we shift from the low-rise to mid-rise and further increases from mid-rise to highrise buildings.

- It is important to go for site specific spectra to get more precise results.

- Damage probabilities of buildings from the actual behavior varies to a great extent from those obtained using HAZUS MH2.0, which shows that the latter's direct applicability is of concern as it underestimates the results.

\section{ACKNOWLEDGEMENT}

The author would like to thank Mr. DhavalBhindora and Mr. YashSaraiya, Research Scholars (M.Tech, Structural Engineering Design Programme) of CEPT University for their valuable support in the research.

\section{REFERENCES}

[1] IS1893 part-1. 2002. Criteria for Earthquake Resistant Design of Structures : Part 1 General provisions and Buildings. Delhi: Bureau of Indian standards.

[2] NBCI. 2005. National Building Code of India. New Delhi: Bureau of Indian standards.

[3] FEMA356. 2000. Prestandard amd Commentary for the Seismic Rehabilitation of Buildings. Washington D.C.: Federal Emergency Management Agency, ASCE.
[4] FEMA. 2012. Multi-hazard Loss Estimation Methodology; HAZUS-MH 2.0. Washington, D.C.: Department of Homeland Security, FEMA, Mitigation division.

[5] Yeh, C. H., Loh, C. H. \& Tsai, K. C. 2003. Development of Earthquake Assessment Methodology in NCREE. Proceedings of joint NCREE/JRC workshop. Taipei, Taiwan.

[6] Rossetto, T. \& Elnashai, A.S. 2003. Derivation of vulnerability functions for European-type RC structures based on observational data. Engineering Structure, 25(10):1241-63.

[7] ATC-13. 1985. Earthquake damage evaluation data for California. Applied Technology Council, Redwood City. California.

[8] Jeong, S.E. \& Elnashai, A.S. 2007. Probabilistic fragility analysis parameterized by fundamental response quantities. Engineering Structures, 29: 1238-1251.

[9] Erberik, M.A. \& Elnashai, A.S. 2004. Fragility analysis of flat-slab structures . Engineering Structures, 26(7):937-48.

[10] Torkamani, H.H., Bargi, K. \& Amirabadi, R. 2013. Fragility Curves Derivation for a Pile-Supported Wharf. International journal of maritime technology, Vol.1/No. 1.

[11] Goody J., Chandler R., Clancy J., Dixon D. \& Wooding G. 2010. Building Type Basics for Housing, Second edition. John Wiley and sons, inc.

[12] IS456. 2000. Plain and Reinforced Concrete - Code of Practice. New Delhi: Bureau of Indian Standards.

[13] IS875 part-1. 1987. Code of Practice for Design Loads (Other than Earthquake) for Buildings and Structures, Dead Loads. New Delhi: Bureau of Indian Standards.

[14] IS875 part-2. 1987. Code of Practice for Design Loads (Other than Earthquake) for Buildings and Structures, Imposed Loads . New Delhi: Bureau of Indian Standards.

[15] IS875 part-3. 1987. Code of Practice for Design Loads (Other than Earthquake) for Buildings and Structures, Wind Loads. New Delhi: Bureau of Indian Standards.

[16] SAP2000. 2004. Version 15.0 - Integrated Software for Structural Analysis and Design, Computers and Structures, Inc., Berkeley, CA.

[17] ATC-40. (1996). Recommended methodology for seismic evaluation and retrofitting of buildings, Report No. Applied Technology Council, Redwood City, California.

[18] IBC. 2009. International Building Code. USA: International Code Council.

[19] Chopra S., Kumar, D. \& Rastogi, B. K. 2010. Estimation of strong ground motions for 2001 Bhuj $(\mathrm{Mw}=7.6)$, India earthquake. Pure Appl. Geophys. Earth and Env. Sci., 167, 1317-1330. 
[20] Shukla, J \& Choudhary, D. 2012. Estimation of seismic ground motions using deterministic approach for major cities of Gujarat. Nat. Hazards Earth Syst. Sci., 2019-2037.

[21] PEER Ground Motion Database. 2010. Pacific earthquake engineering research center. California: The University of California.

\section{BIOGRAPHIE}

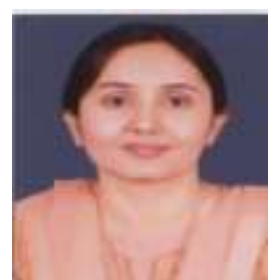

Dr. Dhara shah is an Assistant Professor at Masters Program in Structural Design at Faculty of Technology in CEPT University, since 2006. Prior to CEPT, she worked as a structural engineer for two years in a consultancy firm of structural design. She graduated in Civil engineering from Nirma University and did her M.Tech in Structural Design from CEPT University. She has received her $\mathrm{PhD}$. degree from Gujarat Technological University. Her major area of research includes performance based seismic design of structures and vibration impact assessment of structures. 